Proc. Estonian Acad. Sci. Biol. Ecol., 2006, 55, 4, 267-279

\title{
Isoenzyme diversity and affinity between Dactylis glomerata and Puccinellia maritima (Poaceae)
}

\author{
Georgi B. Angelov
}

Institute of Botany, Bulgarian Academy of Sciences, Acad. G. Bonchev Str., bl. 23, 1113 Sofia, Bulgaria; gbangv@bio.bas.bg

Received 17 June 2005, in revised form 26 September 2005

\begin{abstract}
Two Estonian populations of Dactylis glomerata and two of Puccinellia maritima were surveyed electrophoretically for eight enzymes to assess their diversity and affinity. Analysis of electrophoretic data indicated a significant amount of variability in the studied populations of D. glomerata and P. maritima as judged by the number of isoenzyme phenotypes and isoforms detected. Phenotypic affinity between $D$. glomerata and P. maritima was evaluated by calculating four coefficients of similarity/distance: SI, $D_{\mathrm{CD}}, I_{h}$, and $D_{\mathrm{E}}$. Phenetic analysis demonstrated that $D$. glomerata and P. maritima are more distantly positioned in comparison to other closely related grass species that share common genomes. Systematic position and affinity between Dactylis and Puccinellia within Poaceae are briefly discussed.
\end{abstract}

Key words: Poaceae, Dactylis glomerata, Puccinellia maritima, isoenzyme diversity, affinity.

\section{INTRODUCTION}

Electrophoretic analysis of isoenzymes has become particularly prominent in systematics and evolutionary biology. Isoenzymes are widely employed for revealing the genetic structure of plant populations and assessing the genetic relationships among different taxa (Gottlieb, 1981; Crawford, 1985). Enzyme electrophoresis is also used for addressing questions in plant systematics (Gottlieb, 1977; Crawford, 1989). There are numerous isoenzyme studies in grasses, mainly in the tribe Triticeae, which includes some of most important crops (e.g. Jaaska, 1981, 1996; Hart, 1983; Doebley et al., 1984; McIntyre, 1988; Wendel et al., 1988; Jarvie \& Barkworth, 1990). 
There are relatively few studies in the tribe Poaceae, which encompasses the genera Dactylis and Puccinellia (Tzvelev, 1976). Lumaret (1984) observed clinal variation along both altitudinal and longitudinal gradients in the GOT-1 locus of diploid and tetraploid populations of D. glomerata. Allozymes were employed to analyse association between quantitative traits and heterozygosity in tetraploid D. glomerata (Tomekpe \& Lumaret, 1991) and genetic introgression between tetraploid ssp. glomerata and ssp. reichebachii (Gautier \& Lumaret, 1999). Allozyme polymorphism in the subtropical group of $D$. glomerata was examined by Sahuquillo \& Lumaret (1995). Isoenzyme studies in the genus Puccinellia are rather scarce. Jefferies \& Gottlieb (1983) studied genetic variation within and between three populations of the sterile hybrid Puccinellia $\times$ phryganodes. Isozyme variation in the $P$. nuttalliana complex provided evidence of species boundaries that have not been recognized previously by morphological criteria (Davis \& Manos, 1991; Davis \& Goldman, 1993). Using isoenzyme analysis these authors have presented evidence for the existence of six possibly cryptic species within the morphological species $P$. nuttalliana. The origin of $\times$ Pucciphippsia vacilans, an intergeneric hybrid between Phippsia algida and Puccinellia vahliana, was examined by means of isoenzymes (Steen et al., 2004).

This paper reports on the detected isoenzyme variation in Estonian populations of Dactylis glomerata L. and Puccinellia maritima (Huds.) Parl. The present study, to my knowledge, is the first one dealing with the electrophoretic variability of enzymes in $P$. maritima. The species D. glomerata is common in Estonia, cultivated for hay and in pastures. The species $P$. maritima is not rare on the western seashore of Estonia, but it is rare on the northern one (Gudzinskas et al., 2003). The species D. glomerata is a polyploid complex. Diploids are restricted to very specialized habitats while tetraploids are widely distributed in many variable environments (Lumaret, 1984). The species P. maritima is also a polyploid complex where octoploids $(2 \mathrm{n}=56)$ are prevailing (Hughes \& Halliday, 1980).

The aim of this publication is to present electrophoretic data assessing isoenzyme variation within $D$. glomerata and $P$. maritima and their affinity.

\section{MATERIAL AND METHODS}

In 2000, living plants were collected from natural populations of $D$. glomerata and $P$. maritima and grown in glasshouse prior to analysis. Localities and voucher numbers are given in Table 1. Vouchers are kept at the Herbarium of the Institute of Botany of the Bulgarian Academy of Sciences (SOM). On average, 18-20 individuals per population were subjected to analysis.

Crude extracts were obtained by grinding fresh leaves in buffer of $0.01 \mathrm{M}$ Tris, $0.08 \mathrm{M}$ glycine, $0.005 \mathrm{M}$ cysteine, $20 \%$ sucrose, $\mathrm{pH}$ 8.3. Ion-exchange resin Dowex $1 \times 8(0.4 \mathrm{~g} / 1 \mathrm{~g}$ tissue $)$ was added to the buffer. Extracts were centrifuged 
Table 1. Collection of data for the studied populations of Dactylis glomerata and Puccinellia maritima

\begin{tabular}{c|cc}
\hline Species & Locality & $\begin{array}{c}\text { Voucher } \\
\text { number }\end{array}$ \\
\hline Dactylis glomerata & Saaremaa Island, Salme, 16.08.2000 & Co-1037 \\
& Laelatu, Virtsu, 14.08.2000 & Co-1038 \\
Puccinellia maritima & Hiiumaa Island, Kõpu Peninsula, Kalana, 17.08.2000 & Co-1036 \\
& Saaremaa Island, Läätsa, 15.08.2000 & Co-1035
\end{tabular}

at $10000 \mathrm{rpm}$ for $10 \mathrm{~min}$. The supernatant was used as a source of enzymes. Electrophoresis of the enzymes tetrazolium oxidase (TO), aspartate aminotransferase (AAT), acid phosphatase (ACP), glutamate dehydrogenase (GDH), glucose-6-phosphate dehydrogenase (G-6PDH), and 6-phosphogluconate dehydrogenase (6-PGDH) was carried out in anodal direction using 7.5\% polyacryalamide gel in vertical slabs (Davis, 1964). The enzymes esterase (EST) and peroxidase (PER) were resolved in the cathodal direction following the procedure of Reisfeld et al. (1962). The length of the separating gel for TO, cathodal EST, and cathodal PER was $6 \mathrm{~cm}$. The rest of the enzymes were resolved on $5 \mathrm{~cm}$ long gels. Electrophoresis in the cathodal direction was carried out until the indicator dye, pyronin G, reached the gel end ( 1 front), while the duration of electrophoresis in the anodal direction was 1.5 fronts of the indicator bromphenol blue for all the enzymes surveyed. Gels were stained according to Baur \& Schorr (1969) for TO, Przybylska et al. (1982) for AAT and PER, Korochkin et al. (1977) for ACP, Schmidt-Stohn \& Wehling (1983) for EST, Shaw \& Prasad (1970) for GDH and G-6PDH, and Yeh \& O'Malley (1980) for 6-PGDH. Each isoform was assigned a number equal to its gel migration (in mm) from the start (Perez de la Vega \& Allard, 1984).

If the genetic basis of enzyme systems examined is not known, the use of phenotypic analysis based on isoform presence/absence and frequency data is preferable. It prevents genetic misinterpretation and makes results more objective. For the purposes of phenotypic analysis four measures of similarity/distance were calculated. Presence/absence data were used to determine the similarity index of Jaccard SI (cf. Chung et al., 1991) according to the following formula:

$$
\mathrm{SI}=\frac{M}{M+N}
$$

where $M$ is the number of isoforms common for both taxa and $N$ is the sum of species specific isoforms.

Mean frequencies of isoforms (electrophoretic bands) were calculated by averaging over the studied populations of each species.

Using isoform frequency data, mean values of divergence coefficient $D_{\mathrm{CD}}$ (cf. Stuessy, 1990) and Hedrick's measure of phenotypic identity $I_{h}$ (Hedrick, 1971) 
were calculated for the five most polymorphic enzymes (TO, AAT, ACP, EST, and PER) according to the equations:

$$
D_{\mathrm{CD}}=\left[\frac{1}{N} \sum_{i=1}^{N}\left(x_{i j}-x_{i k}\right)^{2}\right]^{\frac{1}{2}},
$$

where $N$ is the total number of isoforms for each enzyme, $x_{i j}$ and $x_{i k}$ are the mean frequencies of the $i$ th isoform in the taxa $j$ and $k$, and

$$
I_{h}=\frac{2 \sum_{j=1}^{n} P_{j x} P_{j y}}{\sum_{j=1}^{n} P_{j x}^{2}+\sum_{j=1}^{n} P_{j y}^{2}},
$$

where $P_{j x}$ and $P_{j y}$ are the mean frequencies of the $j$ th isoform in the species $x$ and $y$ and $n$ is the number of isoforms of each enzyme.

Euclidean distance $\left(D_{\mathrm{E}}=N \times D_{\mathrm{CD}}\right)$ was calculated using the same data set.

\section{RESULTS AND DISCUSSION}

\section{Tetrazolium oxidase}

The isoenzyme phenotypes (electrophoretic patterns) of TO in D. glomerata and P. maritima are presented in Fig. 1. Two isoenzyme phenotypes (1 and 2) were observed in $D$. glomerata, whereas three other phenotypes $(3,4$, and 5$)$ were

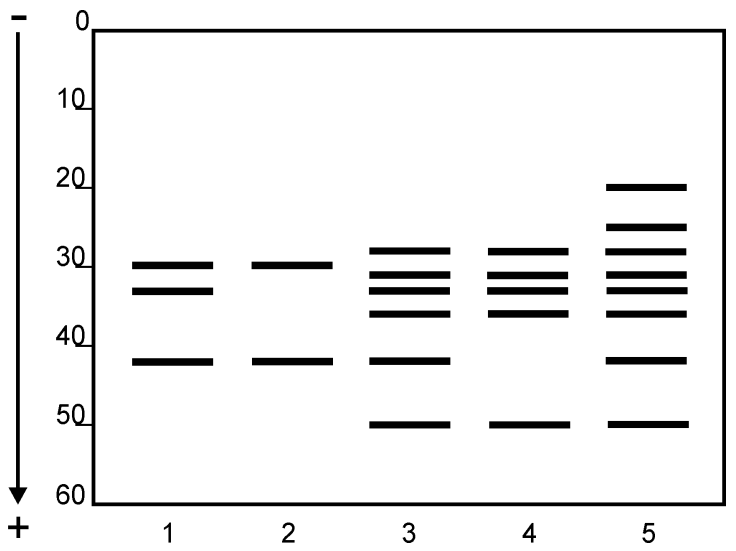

Fig. 1. Isoenzyme phenotypes of TO in Dactylis glomerata and Puccinellia maritima. Phenotypes 1 and $2-D$. glomerata; isophenotypes 3,4 , and $5-P$. maritima. The scale is in $\mathrm{mm}$. The start is at top. 
Table 2. Mean frequencies of TO isoforms in Dactylis glomerata and Puccinellia maritima

\begin{tabular}{l|c|c|c|c|c|c|c|c|c}
\hline \multirow{2}{*}{ Species } & \multicolumn{10}{c}{ Isoforms } \\
\cline { 2 - 10 } & 20 & 25 & 28 & 30 & 31 & 33 & 36 & 42 & 50 \\
\hline D. glomerata & 0.00 & 0.00 & 0.00 & 1.00 & 0.00 & 1.00 & 0.00 & 1.00 & 0.00 \\
P. maritima & 0.12 & 0.12 & 1.00 & 0.00 & 1.00 & 1.00 & 1.00 & 0.25 & 1.00
\end{tabular}

found in P. maritima. Mean frequencies of TO isoforms in the studied populations of D. glomerata and P. maritima are given in Table 2. Isoform 30 was diagnostic of D. glomerata, being monomorphically fixed. Isoforms $20,25,28,31,36$, and 50 were specific for P. maritima. Most of them were invariant, thus pointing to the limited diversity of this species. The enzyme TO clearly differentiated $D$. glomerata and P. maritima as only two out of nine isoforms (33 and 42) proved to be common for the species examined and each of them had its own pattern of TO phenotypes.

\section{Aspartate aminotransferase}

The isoenzyme phenotypes of AAT are shown in Fig. 2. Five isoenzyme phenotypes $(1,4,5,6,7)$ were characteristic of $D$. glomerata. Two phenotypes (8 and 9) were specific for P. maritima and two phenotypes (2 and 3 ) were shared by both species. Phenotypes 3 and 4 possess identical sets of slow-migrating isoforms (triplet 14/15.5/17) and differ in the fast-migrating zone because isoform 31 is not present in phenotype 3. Phenotypes 8 and 9 differ in both slow- and fastmigrating zones. Two different triplets $(11 / 12.5 / 14$ and $14 / 15.5 / 17)$ occur in the slow-migrating zone of phenotypes 8 and 9 , respectively. Both phenotypes could also be distinguished by the presence of isoform 31 (phenotype 8 ) and by

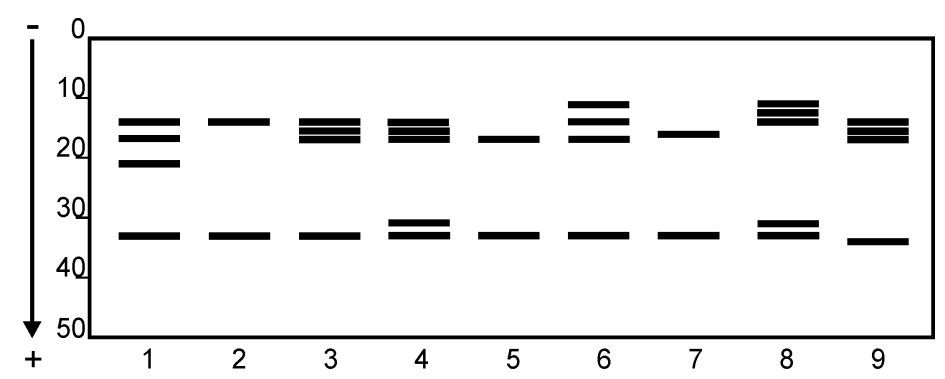

Fig. 2. Isoenzyme phenotypes of AAT in Dactylis glomerata and Puccinellia maritima. Phenotypes $1,4,5,6$, and $7-D$. glomerata; phenotypes 8 and $9-P$. maritima; phenotypes 2 and $3-D$. glomerata and $P$. maritima. The scale is in $\mathrm{mm}$. The start is at top. 
Table 3. Mean frequencies of AAT isoforms in Dactylis glomerata and Puccinellia maritima

\begin{tabular}{l|cccc|c|c|c|c|c|c|c}
\hline \multirow{2}{*}{ Species } & \multicolumn{10}{c}{ Isoforms } \\
\cline { 2 - 11 } & 11 & 12.5 & 14 & 15.5 & 16 & 17 & 21 & 31 & 33 & 34 \\
\hline D. glomerata & 0.10 & 0.00 & 0.50 & 0.30 & 0.10 & 0.80 & 0.10 & 0.20 & 1.00 & 0.00 \\
P. maritima & 0.62 & 0.62 & 1.00 & 0.25 & 0.00 & 0.25 & 0.00 & 0.62 & 0.88 & 0.12
\end{tabular}

the faster migrating isoform 34 (phenotype 9). Aspartate aminotransferase is a dimeric enzyme (Scandalios \& Sorensen, 1975; Huang et al., 1986). It could be assumed that the occurrence of symmetrical three-banded triplets in the slowmigrating zone is an indication of heterozygosity of a putative locus in this zone. Heterozygous triplets of AAT have been regularly observed in other grass taxa (Doebley et al., 1984; Jaaska, 1981, 1994, 1998; Oja, 1998). The isoenzyme structure of the studied populations of D. glomerata and P. maritima is presented in Table 3. It should be noticed that isoforms 15.5 and 16 differed very slightly in their electrophoretic mobility, but they could be distinguished reliably when run side by side. Isoforms 16 and 21 were specific for D. glomerata, whereas isoforms 12.5 and 34 were detected in the populations of $P$. maritima.

\section{Acid phosphatase}

In total, nine isoenzyme phenotypes of ACP were found in the taxa examined (Fig. 3). Most of them (1-6) were characteristic of D. glomerata. Three other isoenzyme phenotypes $(7,8$, and 9$)$ were observed in P. maritima. Judging from the isoenzyme structure (Table 4), it was evident that ACP delimitated the taxa under study, because only two isoforms, 15 and 24, were shared by both species.

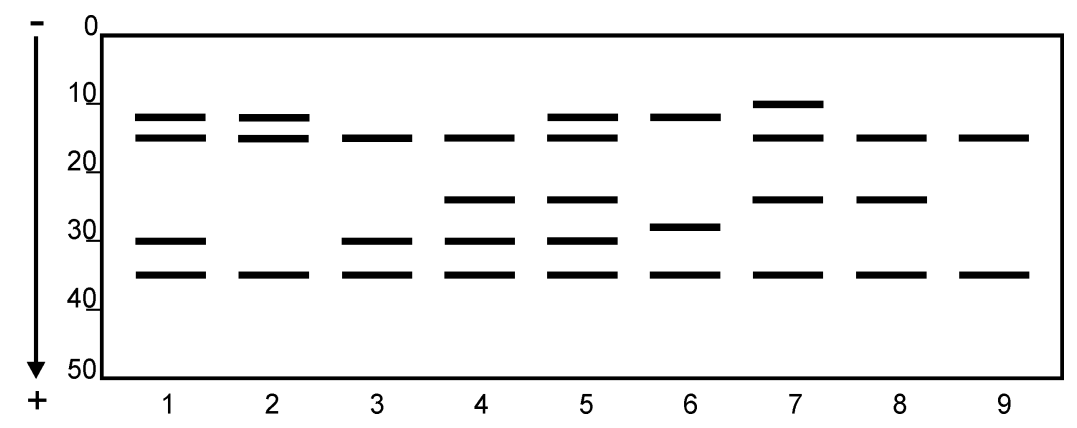

Fig. 3. Isoenzyme phenotypes of ACP in Dactylis glomerata and Puccinellia maritima. Phenotypes $1,2,3,4,5$, and $6-D$. glomerata; phenotypes 7,8 , and $9-P$. maritima. The scale is in $\mathrm{mm}$. The start is at top. 
Table 4. Mean frequencies of ACP isoforms in Dactylis glomerata and Puccinellia maritima

\begin{tabular}{l|c|c|c|c|c|c|c}
\hline \multirow{2}{*}{ Species } & \multicolumn{7}{c}{ Isoforms } \\
\cline { 2 - 8 } & 10 & 12 & 15 & 24 & 28 & 30 & 35 \\
\hline D. glomerata & 0.00 & 0.80 & 0.70 & 0.20 & 0.10 & 0.70 & 0.80 \\
P. maritima & 0.75 & 0.00 & 1.00 & 0.62 & 0.00 & 0.00 & 0.00
\end{tabular}

\section{Cathodal esterase}

Electrophoretic data for the enzyme (Fig. 4, Table 5) also indicated a clear distinction between D. glomerata and P. maritima. The latter species possessed four phenotypes (1-4), while another pair of phenotypes (5 and 6) was detected in D. glomerata. In total, four isoforms of cathodal EST were resolved and each species studied had its own specific isoform of the enzyme.

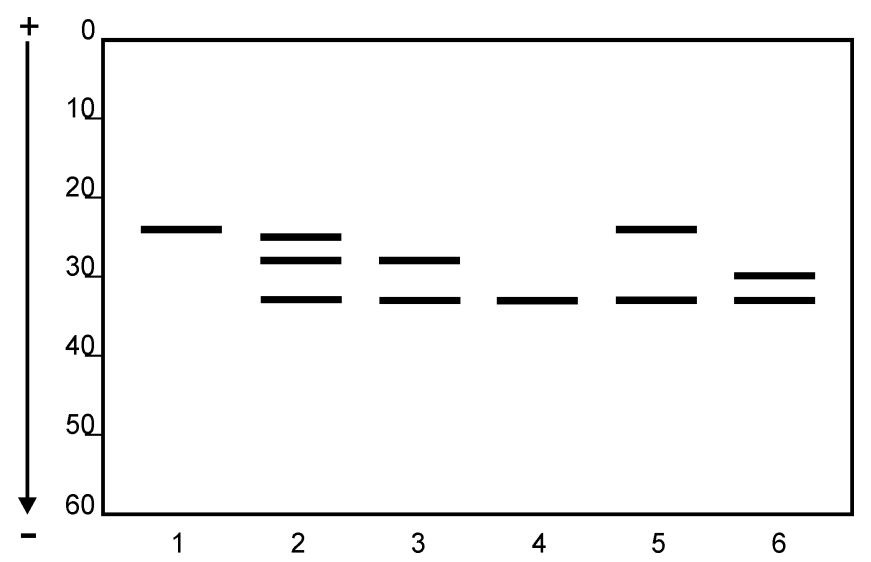

Fig. 4. Isoenzyme phenotypes of cathodal EST in Dactylis glomerata and Puccinellia maritima. Phenotypes $1,2,3$, and $4-P$. maritima; phenotypes 5 and $6-D$. glomerata. The scale is in $\mathrm{mm}$. The start is at top.

Table 5. Mean frequencies of cathodal EST isoforms in Dactylis glomerata and Puccinellia maritima

\begin{tabular}{l|c|c|c|c}
\hline \multirow{2}{*}{ Species } & \multicolumn{4}{|c}{ Isoforms } \\
\cline { 2 - 5 } & 24 & 28 & 30 & 33 \\
\hline D. glomerata & 0.89 & 0.00 & 0.11 & 0.89 \\
P. maritima & 0.20 & 0.20 & 0.00 & 0.87
\end{tabular}




\section{Cathodal peroxidase}

In total, nine isoenzyme phenotypes of cathodal PER were found (Fig. 5). Most of the phenotypes (1-6) pertained to D. glomerata, while three different phenotypes $(7,8$, and 9) were encountered in P. maritima. Mean isoform frequencies of cathodal PER are presented in Table 6. In total 12 isoforms were resolved. Isoforms 28,32 , and 34 were monomorphically fixed and common for both species studied. Three isoforms, 18, 22, 40, were species specific for D. glomerata, whereas isoforms 10 and 36 were detected only in the populations of $P$. maritima.

\section{Glutamate dehydrogenase}

The populations of D. glomerata were monomorphically fixed for isoform 14 , whereas P. maritima proved to be invariant for isoform 12. Jeffrey \& Gottlieb (1983) also found a low level of polymorphism of GDH in another species of Puccinellia. Examination of electrophoretic mobility of GDH in three widely separated populations of $P . \times$ phryganodes revealed three isoenzyme phenotypes of GDH. Due to different experimental conditions, it is difficult to compare our

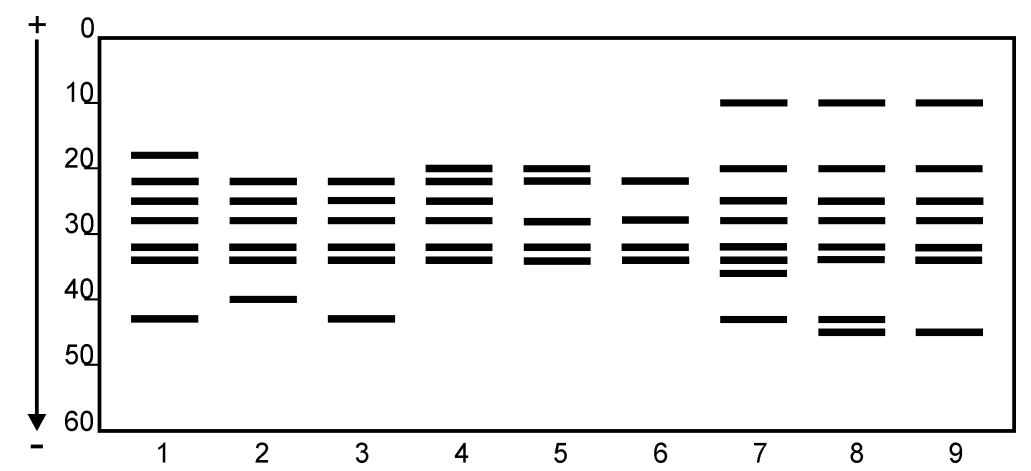

Fig. 5. Isoenzyme phenotypes of cathodal PER in Dactylis glomerata and Puccinellia maritima. Phenotypes $1,2,3,4,5$, and $6-D$. glomerata; phenotypes 7,8 , and $9-P$. maritima. The scale is in $\mathrm{mm}$. The start is at top.

Table 6. Mean frequencies of cathodal PER isoforms in Dactylis glomerata and Puccinellia maritima

\begin{tabular}{l|c|c|c|c|c|c|c|c|c|c|c|c}
\hline \multirow{2}{*}{ Species } & \multicolumn{10}{c}{ Isoforms } \\
\cline { 2 - 15 } & 10 & 18 & 20 & 22 & 25 & 28 & 32 & 34 & 36 & 40 & 43 & 45 \\
\hline D. glomerata & 0.00 & 0.09 & 0.78 & 1.00 & 0.63 & 1.00 & 1.00 & 1.00 & 0.00 & 0.18 & 0.21 & 0.00 \\
P. maritima & 1.00 & 0.00 & 1.00 & 0.00 & 1.00 & 1.00 & 1.00 & 1.00 & 0.50 & 0.00 & 0.28 & 0.71
\end{tabular}


results with those for $P . \times$ phryganodes. Nevertheless, our study is concordant with other studies in grasses (Morden et al., 1989, 1990; Jaaska, 1994) where a limited polymorphism of GDH has been revealed.

\section{Glucose-6-phosphate dehydrogenase}

Isoform 28 was fixed in D. glomerata, while isoform 26 was encountered in the populations of $P$. maritima only.

\section{6-Phosphogluconate dehydrogenase}

An isoenzyme phenotype consisting of isoform pair 18/23 was shared by both taxa examined. A single-banded phenotype (isoform 23 ) was found in D. glomerata, whereas another similar phenotype (isoform 18) was observed in P. maritima.

Analysis of electrophoretic data for all enzymes indicated a significant amount of variability in D. glomerata and P. maritima. A total of 26 and 18 isoenzyme phenotypes were detected in D. glomerata and P. maritima, respectively. Three phenotypes, two for AAT and one for 6-PGDH, were shared by both species. For comparison, 39 isoenzyme phenotypes of 12 enzymes were observed in another species of Puccinellia (Jefferies \& Gottlieb, 1983). Considerable variation for the number of isoforms was also observed. In total 50 isoforms of the eight enzymes examined were electrophoretically resolved in D. glomerata and $P$. maritima -32 isoforms were found in the former species, and 34 isoforms in the latter. Twenty isoforms were common for the two taxa, the rest of isoforms were species specific.

Phenotypic affinity between D. glomerata and P. maritima was assessed in several ways. The values of the similarity coefficient SI ranged from 0.22 for the enzyme TO to 0.54 for the cathodal EST. The mean interspecific value for the five most polymorphic enzymes was 0.39 . A very close but suprisingly low mean value (0.385) of SI was obtained in pair-wise comparisons among several species of Hosta (Chung et al., 1991). The authors assumed that these low affinities are due to forming intralocus heterodimers and possible gene duplications and silencing. The values of SI for comparisons among the grass genera Festucopsis, Agropyron, and Brachypodium vary between 0.37 and 0.44 (Angelov, 2000). A mean value of 0.84 was obtained within a group of closely related red fescue species (Angelov, 1992).

Euclidean distance $D_{\mathrm{E}}$ varied from 0.52 (cathodal EST) to 5.59 (TO), and its mean value was 2.68 . The mean values of $D_{\mathrm{E}}$ for comparisons among closely related grass genera Elytrigia, Psammopyrum, and Trichopyrum were much lower (1.00-1.12) for a similar set of enzymes (Angelov, 2003a). Lower values of $D_{\mathrm{E}}$ imply closer affinity. Hence, the values of $D_{\mathrm{E}}$ for $D$. glomerata and P. maritima indicate a weaker affinity between them. 
In theory, the distance coefficient $D_{\mathrm{CD}}$ may vary from 0 , for species that have the same isoforms at the same frequencies, to 1 , for species that share no isoforms in common. Values of $D_{\mathrm{CD}}$ higher than 0.15 are considered as an indication of a substantial differentiation among the respective taxa. When $D$. glomerata was contrasted to $P$. maritima a mean value of 0.30 was obtained. The comparison among three grass genera Elytrigia, Psammopyrum, and Trichopyrum, which share common genomes, resulted in a much lower value of 0.10 (Angelov, 2003a). Values of 0.19-0.22 were calculated in pair-wise comparisons among Peridictyon sanctum (Festucopsis sancta) and two species of the genus Brachypodium (Angelov, 2003b).

The coefficient of phenotypic identity $I_{h}$ varies from 0 , for species that share no isoforms in common, to 1 , for species that have the same isoforms at the same frequencies. In this study, the values of $I_{h}$ ranged from 0.38 (ACP) to 0.77 (cathodal EST). A mean value of 0.55 was obtained after averaging over the five enzymes. A higher value (0.72) was calculated for comparisons among the Triticeae genera Elytrigia, Psammopyrum, and Trichopyrum, which share common genomes (Angelov, 2003a). Mean values of $0.42-0.45$ were obtained in comparison between Peridictyon and Brachypodium (Angelov, 2003b).

The genera Dactylis and Puccinellia are closely allied in the recent treatments concerning systematics and phylogeny of Poaceae (Tzvelev, 1976, 1989; Soreng \& Davis 1998; Soreng et al., 2003). However, there are some differences among the aforementioned systems in their suprageneric arrangement. The genus Puccinellia is placed either in the subtribe Poinae (Tzvelev, 1976, 1989) or in the subtribe Puccinellinae (Soreng et al., 2003), but in any case Dactylis and Puccinellia are placed nearby in systematic treatments of grasses. Isoenzyme data presented in this study give an insight into the relationships between Dactylis and Puccinellia. Phenotypic analysis demonstrated that Dactylis and Puccinellia are more distantly positioned in comparison to the closely related grass genera Elytrigia, Psammopyrum, and Trichopyrum, which share common genomes within the tribe Triticeae (Angelov, 2003a). Their phenotypic resemblance as revealed by isoenzymes in the present study is comparable to the affinity among Peridictyon, Agropyron, and Brachypodium (Angelov, 2000, 2003b). It should be noted that the monotypic genus Peridictyon has been formerly placed either in Agropyron or Brachypodium, a circumstance which implies a certain degree of affinity. Additional studies including more species and enzymes are needed to determine more precisely the affinity between Dactylis and Puccinellia within Poaceae.

\section{ACKNOWLEDGEMENTS}

Thanks are due to Dr. T. Oja for her assistance in collecting experimental material. Part of the experimental work was done with financial support of the Bulgarian National Scientific Foundation (grant B-1207). 


\section{REFERENCES}

Angelov, G. B. 1992. Biosystematic study of species from genus Festuca L. IV. Electrophoretic analysis of the enzymes peroxidase, acid phosphatase and catalase. Fitologija, 43, 58-67.

Angelov, G. B. 2000. Festucopsis sancta (Janka) Meld. and its relations with Agropyron cristatum (L.) Gaertn. and Brachypodium sylvaticum (Huds.) Beauv. - an electrophoretic survey. Phytol. Balcan., 6(2-3), 217-222.

Angelov, G. B. 2003a. An assessment of the relationships among Elytrigia repens (L.) Nevski, Psammopyrum pycnanthum (Godron) A. Love and Trichopyrum intermedium (Host) A. Love by means of isoenzyme electrophoresis. Herb J. Syst. Bot., 10(1), 13-21.

Angelov, G. B. 2003b. Relationships of Peridictyon sanctum with Brachypodium sylvaticum and B. pinnatum as viewed by isoenzymes. Herb J. Syst. Bot., 10(2), 1-11.

Baur, E. V. \& Schorr, R. T. 1969. Genetic polymorphism of tetrazolium oxidase in dogs. Science, 1666, 1524-1525.

Chung, M. G., Hamrick, J. L., Jones, S. B. \& Derda, G. S. 1991. Isozyme variation within and among populations of Hosta (Liliaceae) in Korea. Syst. Bot., 16, 667-684.

Crawford, D. J. 1985. Electrophoretic data and plant speciation. Syst. Bot., 10, 405-416.

Crawford, D. J. 1989. Enzyme electrophoresis and plant systematics. In Isozymes in Plant Biology (Soltis, D. E. \& Soltis, P. S., eds), pp. 146-164. Dioscorides Press, Portland.

Davis, B. J. 1964. Disc electrophoresis. I. Method and application to human serum proteins. Ann. N. Y. Acad. Sci., 12, 404-427.

Davis, J. I. \& Goldman, D. H. 1993. Isozyme variation and species delimitation among diploid populations of the Puccinellia nuttalliana complex: character fixation and the discovery of phylogenetic species. Taxon, 42, 585-599.

Davis, J. I. \& Manos, P. S. 1991. Isozyme variation and species delimitation in the Puccinellia nuttalliana complex (Poaceae): an application of the phylogenetic species concept. Syst. Bot., 16, 431-445.

Doebley, J. F., Goodman, M. M. \& Stuber, C. W. 1984. Isoenzymatic variation in Zea (Graminae). Syst. Bot., 9, 203-218.

Gautier, M. F. \& Lumaret, R. 1999. Genetic introgression between tetraploid Dactylis glomerata ssp. reichenbachii and glomerata in the French Alps. Insight from morphological and isoenzyme variation. Pl. Syst. Evol., 214, 219-234.

Gottlieb, L. D. 1977. Electrophoretic evidence and plant systematics. Ann. Missouri Bot. Gard, 64, $161-180$.

Gottlieb, L. D. 1981. Electrophoretic evidence and plant systematics. Progr. Phytochem., 7, 1-46.

Gudzinskas, Z., Kraal, H. \& Tabaka, L. 2003. Genus Puccinellia. In Flora of the Baltic Countries, Vol. 3 (Kuusk, V., Tabaka, L. \& Jankeviciene, R., eds), pp. 312-313. Tartu.

Hart, G. E. 1983. Hexaploid wheat (Triticum aestivum L.) In Isozymes in Plant Genetics and Breeding, Part B (Tanksley, S. D. \& Orton, T. J., eds), pp. 35-56. Elsevier, Amsterdam.

Hedrick, P. W. 1971. A new approach to measuring genetic similarity. Evolution, 25, 276-280.

Huang, A., Kin, L. \& Youle, R. 1986. Organelle-specific isozymes of aspartate- $\alpha$-ketoglutarate transaminase in spinach leaves. Pl. Physiol., 58, 110-113.

Hughes, W. E. \& Halliday, G. 1980. Genus Puccinellia. In Flora Europea, Vol. 5 (Tutin, T. G. et al., eds), pp. 167-169. Cambridge University Press.

Jaaska, V. 1981. Aspartate aminotransferase and alcohol dehydrogenase isoenzymes: intraspecific differentiation in Aegilops taushii and the origin of the D genome polyploids in the wheat group. Pl. Syst. Evol., 137, 259-273.

Jaaska, V. 1994. Isoenzyme evidence on the systematics of Hordeum section Marina (Poaceae). Pl. Syst. Evol., 191, 213-226.

Jaaska, V. 1996. Isoenzyme data on the origin of allotetraploid Elymus species. In Proceedings of the 2nd Triticeae Symposium (Wang, R., Jensen, K. \& Jaussi, C., eds), pp. 165-168. Logan, Utah. 
Jaaska, V. 1998. Isoenzyme data on the diploid progenitors of North American allotetraploid Elymus species. In Proceedings of the 3rd Triticeae Symposium (Jaradat, A., ed.), pp. 209216. Science Publishers, USA.

Jarvie, J. R. \& Barkworth, M. E. 1990. Isozyme similarity in Thinopyrum and its relatives (Triticeae: Gramineae). Genome, 33, 885-891.

Jefferies, R. L. \& Gottlieb, L. D. 1983. Genetic variation within and between populations of the asexual plant Puccinellia $\times$ phryganodes. Amer. J. Bot., 61, 774-779.

Korochkin, L., Serov, O., Pudovkin, A., Maletski, C., Polyakova, E. \& Manchenko, G. 1977. Genetics of Isoenzymes. Nauka, Moskva (in Russian).

Lumaret, R. 1984. The role of polyploidy in the adaptive significance of polymorphism at the GOT 1 locus in the Dactylis glomerata complex. Heredity, 52, 153-169.

McIntyre, C. L. 1988. Variation in isozyme loci in Triticeae. Pl. Syst. Evol., 160, 123-142.

Morden, C. W., Doebley, J. F. \& Shertz, K. F. 1989. Allozyme variation in Old World races of Sorghum bicolor (Poaceae). Am. J. Bot., 76, 247-255.

Morden, C. W., Doebley, J. F. \& Shertz, K. F. 1990. Allozyme variation among the spontaneous species of Sorghum section Sorgum (Poaceae). Theor. Appl. Genet., 80, 296-304.

Oja, T. 1998. Isoenzyme diversity and phylogenetic affinities in the section Bromus of the grass genus Bromus (Poaceae). Biochem. Syst. Ecol., 26, 403-413.

Perez de la Vega, M. \& Allard, R. W. 1984. Mating system and genetic polymorphism in populations of Secale cereale and S. vavilovii. Can. J. Genet. Cytol., 26, 306-317.

Przybylska, J., Blixt, S., Parzysz, H. \& Zimniak-Przybylska, Z. 1982. Isoenzyme variation in the genus Pisum. I. Electrophoretic patterns of several enzyme systems. Genet. Pol., 23, 103 121.

Reisfeld, R. A., Lewis, U. J. \& Williams, D. E. 1962. Disc electrophoresis of basic proteins and peptides on polyacrylamide gels. Nature, 195, 281-283.

Sahuquillo, E. \& Lumaret, R. 1995. Variation in the subtropical group of Dactylis glomerata. 1. Evidence from allozyme polymorphism. Biochem. Syst. Ecol., 23, 407-418.

Scandalios, J. G. \& Sorensen, J. 1975. Genetic control and intracellular localization of glutamate oxaloacetate transaminase in maize. Biochem. Genet., 13, 759-769.

Schmidt-Stohn, G. \& Wehling, P. 1983. Genetic control of esterase isoenzymes in rye (Secale cereale L.). Theor. Appl. Genet., 64, 109-115.

Shaw, C. R. \& Prasad, R. 1970. Starch gel electrophoresis of enzymes - a compilation of recipes. Biochem. J., 4, 297-320.

Soreng, R. J. \& Davis, J. I. 1998. Phylogenetic and character evolution in the grass family (Poaceae): Simultaneous analysis of morphological and chloroplast DNA restriction site character sets. Bot. Rev., 64, 1-85.

Soreng, R. J., Peterson, P. M., Davidse, G., Judziewicz, E. J., Zuloaga, F. O., Filgueiras, T. S. \& Morrone, O. 2003. Catalogue of New World grasses (Poaceae): IV. Subfamily Pooideae. Contr. U.S. Natl. Herb., 48, 13-14.

Steen, N., Elven, R. \& Nordal, I. 2004. Hybrid origin of the arctic $\times$ Pucciphyppsia vacilans (Poaceae): evidence from Svabard plants. Pl. Syst. Evol., 245, 215-238.

Stuessy, T. F. 1990. Plant Taxonomy. Columbia University Press, New York.

Tomekpe, K. \& Lumaret, R. 1991. Association between quantitative traits and allozyme heterozygosity in a tetraploid species Dactylis glomerata. Evolution, 45, 359-368.

Tzvelev, N. N. 1976. Grasses of USSR. Nauka, Leningrad (in Russian).

Tzvelev, N. N. 1989. The system of grasses (Poaceae) and their evolution. Bot. Rev., 55, 142-204.

Wendel, J. F., Goodman, M. M., Stuber, C. W. \& Beckett, J. E. 1988. New isozyme systems for maize (Zea mays L.). Biochem. Genet., 26, 421-445.

Yeh, F. C. \& O'Malley, M. D. 1980. Enzyme variation in natural populations of Douglas fir (Pseudotsuga menziesii (Mirb.) Franco) from British Columbia. Silvae Genet., 29, 83-92. 


\title{
Dactylis glomerata ja Puccinellia maritima (Poaceae) isoensü̈̈mne varieeruvus ning sugulus
}

\author{
Georgi B. Angelov
}

Elektroforeetiliselt on uuritud kaheksat ensüümi Dactylis glomerata ja Puccinellia maritima neljas Eesti populatsioonis nende geneetilise mitmekesisuse ja sugulusastme hindamiseks. Elektroforeesi andmete analüüs leitud isoensüümfenotüüpide ja isovormide alusel viitab olulisele varieeruvusele $D$. glomerata ja $P$. maritima uuritud populatsioonides. Fenotüüpset afiinsust (sugulust, sarnasust) D. glomerata ja $P$. maritima vahel on hinnatud nelja sarnasus-/distantskoefitsiendi - SI, $D_{\mathrm{CD}}, I_{h}$ ja $D_{\mathrm{E}}$ - arvutamise teel. Feneetiline analüüs näitab, et $D$. glomerata ja $P$. maritima erinevad omavahel rohkem kui teised lähedased kõrreliste liigid, millel on ühine genoom. Lühidalt on käsitletud Dactylis'e ja Puccinellia positsiooni ja sugulust kõrreliste sugukonnas Poaceae. 